\title{
PENGARUH TEKNIK AKROSTIK TERHADAP KETERAMPILAN MENULIS PUISI SISWA KELAS V SD ISLAM AL AMANAH TANGERANG SELATAN
}

\author{
Nafia Wafiqni ${ }^{1)}$, Aida Rosdiani ${ }^{2)}$ \\ UIN Syarif Hidayatullah Jakarta1), SDS Azhari Islamic School Cilandak2) \\ Email: nafia.wafiqni@uinjkt.ac.id ${ }^{1}$,rosdianiaida@gmail.com²)
}

Naskah diterima : 2 Maret 2019, direvisi : 10 April 2019, disetujui : 20 April 2019

\begin{abstract}
Abstrak
The Purpose of the study is to know Influence of Acrostic Technique to Poetry Writing Skills of Students. It was conducted at Al Amanah Islamic Elementary School South Tangerang, $5^{\text {th }}$ grade semester 2015/2016. The method used in this study was quasi-experiment with NonEquivalent Control Grup Design. Samples were taken by purposive sampling. The first samples included 36 students of experimental class using acrostic technique and 34 students of control class using conventional learning. Based on posttest score, average poetry writing skill of experiment class students who using acrostic technique was higher than average poetry writing skill of controll class students who using conventional learning method. The average pretest score of experiment class was 64,28, while of the control class was 61,21. On the other side, the averafe posttest scored of experiment class was74,89 and the control class was 70,00. Hipothesis two class calculation using T-tes, Paired Sample T Test, achived the significance level of 0,050 showing that probability value (significance) was 0,004 . Due to significance of $0,004<\alpha=0,050$, $\mathrm{H}_{0}$ was rejected. This proved that usage of Acrostic Technique Influence to Poetry Writing Skills of Students $5^{\text {th }}$ Grade second semester at Al Amanah Islamic Elementary School South Tangerang 2015/2016.
\end{abstract}

Keywords: Poetry Writing Skills, Acrostic Techniques

Pengutipan: Hani Handayani. (2019). Pengarub Teknik Akrostik Terhadap Keterampilan Menulis Puisi Siswa Kelas V SD Islam Al Amanah Tangerang Selatan. JMIE: Journal of Madrasah Ibtidaiyah Education,3(1), 2019, 72-81. jmie.v3i1.99.

Permalink/DOI: http://dx.doi.org/ 10.32934/jmie.v3i1.99 


\section{PENDAHULUAN}

Bahasa memiliki peranan penting dalam kehidupan manusia. Para ahli merumuskan fungsi bahasa secara umum, yaitu bahasa berfungsi sebagai alat untuk berkomunikasi, mengekpresikan diri, berintegrasi dan beradaptasi sosial, serta sebagai alat kontrol sosial. Berdasarkan fungsi bahasa secara umum, bahasa Indonesia pun memiliki peran dan fungsi yang sangat penting bagi bangsa Indonesia yaitu sebagai bahasa Negara dan bahasa Nasional. Mengingat fungsi yang dimiliki oleh bahasa Indonesia sangat banyak, maka kita perlu mengadakan pembinaan dan pengembangan terhadap keterampilan berbahasa Indonesia.

Keterampilan berbahasa pada pendidikan formal mencakup empat segi keterampilan, yaitu keterampilan menyimak, keterampilan berbicara, keterampilan membaca, dan keterampilan menulis. Setiap keterampilan itu dapat diperoleh melalui praktik dan latihan. Salah satu aspek keterampilan berbahasa yang komplek untuk dipelajari dan dikuasai siswa adalah keterampilan menulis. Dalam Kurikulum Tingkat Satuan Pendidikan (KTSP) disebutkan bahwa menulis merupakan keterampilan yang harus diajarkan dan dikuasai oleh siswa. Keterampilan menulis merupakan salah satu keterampilan dari empat komponen keterampilan yang terdapat pada mata pelajaran bahasa Indonesia. Menurut Tarigan, menulis adalah keterampilan berbahasa yang dipergunakan untuk berkomunikasi secara tidak langsung dan tidak dilakukan secara tatap muka dengan orang lain (Tarigan, 2008; 3). Pembelajaran bahasa Indonesia diarahkan untuk dapat meningkatkan kemampuan peserta didik agar mampu berkomunikasi dengan baik dan benar, komunikasi yang dilakukan secara lisan maupun tulisan, serta menumbuhkan apresiasi terhadap hasil karya sastra.

Salah satu pembelajaran bahasa Indonesia yang diajarkan di Sekolah Dasar adalah pembelajaran sastra yang bertujuan untuk menumbuhkan keterampilan siswa terhadap suatu karya sastra. Pengajaran sastra dikembangkan dalam kompetensi dasar yaitu siswa mampu mengapresiasi dan berekspresi sastra melalui kegiatan mendengar, menonton, membaca, dan melisankan hasil karya sastra berupa dongeng, puisi, dan drama pendek, serta menuliskan pengalaman dalam bentuk cerita dan puisi. Salah satu standar kompetensi yang harus dicapai siswa untuk terampil dalam menulis sastra terdapat pada siswa Kelas V, yaitu mengungkapkan pikiran, perasaan, informasi, dan fakta secara tertulis dalam bentuk ringkasan, laporan dan puisi bebas. Berdasarkan standar kompetensi tersebut, keterampilan menulis yang berhubungan dengan pembelajaran sastra di Kelas V semester genap adalah menulis puisi bebas. Maka Peneliti memfokuskan penelitian pada pembelajaran menulis puisi.

Menulis puisi merupakan salah satu keterampilan sastra yang harus dicapai siswa, karena siswa akan memeroleh banyak manfaat dari kegiatan menulis puisi tersebut. Puisi merupakan karya sastra yang paling imajinatif dan mendalam mengenai alam sekitar, diri sendiri, termasuk hubungan manusia dengan manusia, serta hubungan manusia dengan Tuhan Yang Maha Kuasa. Sesuai dengan pendapat Burhan Nurgiantoro, bahwa puisi adalah sebuah genre sastra yang sangat memerhatikan pemilihan aspek kebahasaannya (Nurgiyantoro, 2005: 312).Beberapa manfaat menulis puisi adalah siswa dapat mengekspresikan pikirannya melalui bahasa yang indah 
dalam puisi dan siswa dapat menjadikan puisi sebagai media untuk menuangkan segala hal yang dirasakan. Keterampilan menulis puisi ini tentunya dapat diperoleh melalui proses pembelajaran. Secara prinsipil, pembelajaran menulis puisi harus dipahami guru agar pengelolaan pembelajaran dapat berlangsung dengan baik sehingga siswa dapat belajar dengan penuh makna. Kebermaknaan menulis puisi bagi siswa merupakan modal dasar untuk menumbuhkembangkan sikap positifnya terhadap bahasa Indonesia sebagai bahasa nasional. Pembelajaran menulis puisi juga harus memiliki tujuan yang jelas, agar tercipta suasana belajar yang menyenangkan sehingga siswa dapat belajar secara optimal dan terarah.

Berdasarkan hasil wawancara yang peneliti lakukan dengan salah satu guru mata pelajaran Bahasa Indonesia di SD Islam Al Amanah Tangerang Selatan, khususnya di kelas V peneliti menemukan masalah pada keterampilan menulis puisi siswa yang masih rendah. Hal ini disebabkan karena siswa masih merasa kesulitan untuk menuangkan ide atau gagasan yang dimiliki dalam bentuk puisi. Ide atau gagasan siswa masih tidak terstruktur dan terinci dengan baik sehingga pengungkapannya dalam puisi kurang runtut. Adapun Hambatan lain yang dialami siswa dalam pembelajaran menulis puisi adalah teknik pembelajaran menulis puisi yang digunakan guru belum bervariasi, guru masih sering menggunakan metode konvensional dalam pembelajaran sehingga membuat siswa merasa malas, jenuh, dan tidak membangkitan motivasi atau minat siswa untuk mengikuti pembelajaran menulis puisi.

Salah satu cara yang diperlukan guru untuk mengatasi rendahnya keterampilan siswa dalam menulis puisi, yaitu dengan menggunakan teknik pembelajaran yang dapat membangkitkan motivasi siswa untuk mengikuti pembelajaran dan memudahkan siswa mendapatkan ide atau gagasan dalam menulis puisi. Peneliti ini akan menggunakan teknik akrostik untuk memudahkan siswa menuangkan ide atau gagasan dalam menulis puisi. Teknik akrostik merupakan teknik menulis puisi yang sangat mudah dipahami dan ditulis, karena prosedur penulisannya ditulis dengan cara mengembangkan larik-larik dalam puisi melalui pengembangan huruf yang disusun ke bawah membentuk sebuah kata (Rusmin \& Dadan, 2007: 177). teknik akrostik ini adalah cara yang dilakukan oleh guru untuk memudahkan siswa mengingat sebuah materi yang ingin diingat dengan cara menggunakan huruf awal, tengah, atau akhir dalam sebuah kalimat atau frase tertentu (Suhadi, 2014:2). Dengan menggunakan teknik akrostik, peneliti berasumsi bahwa teknik tersebut akan lebih memudahkan siswa memiliki keterampilan menulis puisi.

\section{METODE PENELITIAN}

Penelitian ini dilakukan dengan menggunakan metode quasi eksperiment. Metode ini adalah metode yang tidak memungkinkan peneliti melakukan pengontrolan penuh terhadap semua variabel yang relevan. Tetapi pengontrolannya hanya dilakukan terhadap satu variabel, yaitu variabel yang paling dominan (Syaodih, 2012: 59).

Desain penelitian yang digunakan yaitu Non-Equivalent Control Grup Design (Hanafi, 2011:175). Pada desain penelitian ini melibatkan dua kelas, yaitu kelas eksperimen dan kelas kontrol. 
Sebelum diberikan perlakuan pada kedua kelas masing-masing kelas akan diberikan pretest terlebih dahulu, yakni untuk mengetahui kemampuan awal pada siswa. Selanjutnya, kelas eksperimen diberikan perlakuan dengan menggunakan teknik akrostik, sedangkan kelas kontrol menggunakan pembelajaran konvensional. Setelah diberi perlakuan maka kedua kelas diberikan posttest untuk mengetahui kemampuan akhir pada siswa. Berikut tabel rancangan design penelitian Non-Equivalent Control Grup Design.

Target populasi pada penelitian ini adalah seluruh siswa SD Islam Al Amanah Tangerang Selatan pada semester genap Tahun pelajaran 2015/2016. Adapun populasi terjangkau dalam penelitia ini adalah siswa kelas V SD Islam Al Amanah Tangerang Selatan yang terdiri dari dua rombongan belajar yaitu kelas $\mathrm{V}$-A dan V-B.

Sampel pada penelitian ini peneliti menentukan dua kelas dari dua rombongan belajar kelas V SD Islam Al Amanah, yaitu kelas V-A dan V-B yang dijadikan sampel penelitian. Berdasarkan pengambilan sampel tersebut diperoleh kelas V-A sebagai kelas eksperimen dan kelas V-B sebagai kelas kontrol.

Teknik pengumpulan data yang dimaksud dalam penelitian ini adalah cara-cara yang digunakan untuk memeroleh data empiris yang dipergunakan untuk penelitian. Dalam pengumpulan data ini terlebih dahulu menentukan sumber data, variabel penelitian, dan instrumen penelitian. Sumber data yang akan diperoleh dalam penelitian ini berasal dari sampel yang diambil berdasarkan tujuan tertentu (Purposive Sampling). Penelitian ini dilakukan kepada dua kelas, yakni kelas eksperimen yang diberi perlakuan dengan teknik akrostik dan kelas kontrol yang tidak diberi perlakuan. Kelas eksperimen yaitu kelas V-A dengan jumlah 36 siswa dan kelas kontrol yaitu kelas V-B dengan jumlah 34 siswa. Data yang digunakan berupa skor yang diperoleh dari hasil tes keterampilan menulis puisi.

\section{HASIL DAN PEMBAHASAN}

Kelas eksperimen adalah kelas yang diberikan perlakuan dengan menggunakan teknik akrostik pada saat proses pembelajaran menulis puisi berlangsung. Sedangkan kelas kontrol adalah kelas yang diberikan perlakuan dengan menggunakan metode konvensional pada saat proses pembelajaran menulis puisi berlangsung. Sebelum kedua kelas diberikan pembelajaran menulis puisi, maka kedua kelas terlebih dahulu diberikan tes awal (pretest) untuk mengetahui kemampuan awal menulis puisi pada siswa. Data yang diperoleh untuk mengetahui kemampuan awal menulis puisi pada siswa, dihitung menggunakan program SPSS versi 22.00. Adapun rangkuman hasil pengolahan data pretest kedua kelas tersebut dapat dilihat pada tabel berikut ini: 
Tabel 2. Rangkuman Data Statistik Nilai Pretest Menulis Puisi Kelas Eksperimen dan Kelas Kontrol

\begin{tabular}{ccccccccc}
\hline No & Kelas & N & $\begin{array}{c}\text { Nilai } \\
\text { Maksimal }\end{array}$ & $\begin{array}{c}\text { Nilai } \\
\text { Minimal }\end{array}$ & Mean & Median & Modus & $\begin{array}{c}\text { Standar } \\
\text { Deviasi }\end{array}$ \\
\hline 1 & Eksperimen & 36 & 77 & 50 & 64.28 & 63.00 & 63 & 5.946 \\
2 & Kontrol & 34 & 74 & 50 & 61.21 & 61.00 & 61 & 5.454 \\
\hline
\end{tabular}

Setelah kedua kelas diberikan pembelajaran menulis puisi, selanjutnya kelas eksperimen dan kelas kontrol diberi posttest untuk mengetahui kemampuan menulis puisi pada kelas eksperimen yang menggunakan teknik akrostik dan kelas kontrol yang tidak menggunakan teknik akrostik. Hal tersebut dimaksudkan untuk membandingkan kemampuan awal siswa sebelum dan sesudah perlakuan. Data yang diperoleh untuk mengetahui kemampuan awal menulis puisi pada siswa, dihitung menggunakan program SPSS versi 22.00. Adapun rangkuman hasil pengolahan data posttest kedua kelas tersebut dapat dilihat pada tabel berikut ini:

Tabel 3. Rangkuman Data Statistik Nilai Posttest Menulis Puisi Kelas Eksperimen dan Kelas Kontrol

\begin{tabular}{ccccccccc}
\hline No & Kelas & N & $\begin{array}{c}\text { Nilai } \\
\text { Maksimal }\end{array}$ & $\begin{array}{c}\text { Nilai } \\
\text { Minimal }\end{array}$ & Mean & Median & Modus & $\begin{array}{c}\text { Standar } \\
\text { Deviasi }\end{array}$ \\
\hline 1 & Eksperimen & 36 & 90 & 64 & 74.89 & 75.00 & 64 & 7.410 \\
2 & Kontrol & 34 & 80 & 61 & 70.00 & 70.00 & 65 & 5.565 \\
\hline
\end{tabular}

Selanjutnya dilakukan uji normalitas pretest dan posttest. Uji normalitas dilakukan untuk mengetahui sebaran data yang diperoleh dari hasil pretest dan posttest berdistribusi normal atau tidak. Proses perhitungannya menggunakan bantuan SPSS 22.00. Uji normalitas pada penelitian ini menggunakan rumus Kolmogorov-Smirnov dan Shapiro-Wilk. Data pretest-posttest kelas eksperimen dan kelas kontrol dinyatakan berdistribusi normal apabila signifikansi yang diperoleh dari hasil perhitungan lebih besar dari tingkat alpha 5\% (sig. (2-tailed) > 0.050). Hasil perhitungan uji normalitas sebaran data pretest-posttest kemampuan menulis puisi dari kedua sampel penelitian, dapat disajikan dalam tabel sebagai berikut:

Tabel 4. Hasil Uji Normalitas Pretest Kelas Eksperimen dan Kelas Kontrol

\begin{tabular}{ccccccc}
\hline Nilai Pretest & \multicolumn{3}{c}{ Kolmogorov-Smirnov } & \multicolumn{3}{c}{ Shampiro-Wilk } \\
\cline { 2 - 7 } & Statistic & $\mathrm{df}$ & Sig. & Statistic & $\mathrm{df}$ & Sig. \\
\hline eksperimen & .141 & 36 & .069 & .972 & 36 & .476 \\
Kontrol & .137 & 34 & .106 & .959 & 34 & .233 \\
\hline
\end{tabular}


Berdasarkan tabel Kolmogorov-Smirnov di atas, menunjukkan bahwa nilai signifikan pretest pada kelas eksperimen adalah 0,69 dan nilai signifikan pretest pada kelas kontrol adalah 0,106. Sedangkan berdasarkan tabel Shapiro-Wilk di atas, menunjukkan bahwa nilai signifikan pretest pada kelas eksperimen adalah 0,476 dan nilai signifikan pretest pada kelas kontrol adalah 0,233. Hal ini membuktikan bahwa nilai signifikansi dari kelas eksperimen dan kelas kontrol lebih besar dari nilai alpha 0,050. Karena nilai signifikan kedua kelas lebih besar dari nilai alpha 0,050 ((0,069 $>0,050),(0,106>0,050),(0,476>0,050),(0,233>0,050))$, maka data kedua kelas berdistribusi normal.

\section{Tabel 5. Hasil Uji Normalitas Posttest Kelas}

Eksperimen dan Kelas Kontrol

\begin{tabular}{ccccccc}
\hline Nilai Pretest & \multicolumn{3}{c}{ Kolmogorov-Smirnov } & \multicolumn{3}{c}{ Shampiro-Wilk } \\
\cline { 2 - 7 } & Statistic & $\mathrm{df}$ & Sig. & Statistic & $\mathrm{df}$ & Sig. \\
\hline eksperimen & .087 & 36 & .200 & .954 & 36 & .135 \\
Kontrol & .117 & 34 & .200 & .949 & 34 & .115 \\
\hline
\end{tabular}

Berdasarkan tabel Kolmogorov-Smirnov di atas, menunjukkan bahwa nilai signifikan posttest pada kelas eksperimen adalah 0,200 dan nilai signifikan posttest pada kelas kontrol adalah 0,200. Sedangkan berdasarkan tabel Shapiro-Wilk di atas, menunjukkan bahwa nilai signifikan posttest pada kelas eksperimen adalah 0,135 dan nilai signifikan posttest pada kelas kontrol adalah 0,115. Hal ini membuktikan bahwa nilai signifikansi dari kelas eksperimen dan kelas kontrol lebih besar dari nilai alpha 0,050. Karena nilai signifikan kedua kelas lebih besar dari nilai alpha 0,050 ((0,200 $>0,050),(0,200>0,050),(0,135>0,050),(0,115>0,050))$, maka data kedua kelas berdistribusi normal.

Setelah melakukan uji normalitas dan kedua kelas dinyatakan berdistribusi normal, selanjutnya menentukan nilai homogenitas varians pretest dan posttest. Penghitungannya menggunakan bantuan SPSS 22.00. Adapun kriteria pengujian homogenitas adalah sebagai berikut:

a. Jika probabilitas $>0.050$ maka $\mathrm{H}_{0}$ diterima, artinya varians dinyatakan homogen.

b. Jika probabilitas $<0.050$ maka $\mathrm{H}_{0}$ ditolak, artinya varians dinyatakan heterogen.

Hasil perhitungan uji homogenitas varians data, dapat disajikan dalam tabel sebagai berikut:

Tabel 6. Hasil Uji Homogenitas Pretest Kelas

Eksperimen dan Kelas Kontrol

\begin{tabular}{cccc}
\hline Levene Statistic & df1 & df2 & Sig. \\
\hline .760 & 1 & 68 & .387 \\
\hline
\end{tabular}


Berdasarkan hasil uji homogenitas pretest kelas eksperimen dan kelas kontrol pada tabel di atas, menunjukkan bahwa nilai levene statistic 0,760 dan nilai probabilitas (signifikansi) adalah 0,387. Karena nilai signifikansinya lebih besar dari nilai alpha 0,387 > 0,050, maka $\mathrm{H}_{0}$ diterima. Hal ini membuktikan bahwa kedua sampel dari kelas eksperimen dan kelas kontrol berasal dari kelas yang homogen.

\section{Tabel 7. Hasil Uji Homogenitas Posttest Kelas}

Eksperimen dan Kelas Kontrol

\begin{tabular}{cccc}
\hline Levene Statistic & $\mathrm{df1}$ & $\mathrm{df2}$ & Sig. \\
\hline 1.327 & 1 & 68 & .253 \\
\hline
\end{tabular}

Berdasarkan hasil uji homogenitas posttest kelas eksperimen dan kelas kontrol pada tabel di atas, menunjukkan bahwa nilai levene statistic 1,327 dan nilai probabilitas (signifikansi) adalah 0,253. Karena nilai signifikansinya lebih besar dari nilai alpha 0,253 > 0,050, maka $\mathrm{H}_{0}$ diterima. Hal ini membuktikan bahwa kedua sampel dari kelas eksperimen dan kelas kontrol berasal dari kelas yang homogen.

Berdasarkan tabel hasil uji homogenitas pretest-posttest, maka dapat disimpulan bahwa kelas sampel baik pretest maupun posttest memiliki probabilitas $>0,050$, artinya varians dari kedua sampel tersebut dinyatakan homogen.

Berdasarkan hasil uji normalitas dan uji homogenitas menunjukkan bahwa data yang diperoleh berdistribusi normal dan kedua kelas eksperimen dan kontrol bersifat homogen. Selanjutnya dapat dilakukan pengujian hipotesis data dengan menggunakn bantuan SPSS 22.00. Uji hipotesis data posttest kelas eksperimen dan kontrol adalah untuk mengetahui pengaruh penggunaan teknik akrostik terhadap keterampilan menulis puisi pada siswa kelas V. Adapun kriteria pengujian hipotesis adalah sebagai berikut:

a. Jika probabilitas $>0.050$, maka $\mathrm{H}_{0}$ diterima, artinya tidak ada pengaruh penggunaan teknik akrostik terhadap keterampilan menulis puisi pada siswa kelas $\mathrm{V}$.

b. Jika probabilitas $<0.050$, maka $\mathrm{H}_{0}$ ditolak, artinya ada pengaruh penggunaan teknik akrostik terhadap keterampilan menulis puisi pada siswa kelas $\mathrm{V}$. 
Tabel 8. Hasil Uji Hipotesis Kelas Eksperimen dan Kelas Kontrol

Paired Samples Test

\begin{tabular}{|c|c|c|c|c|c|c|c|c|}
\hline \multirow{4}{*}{$\begin{array}{l}\text { Eksperimen } \\
\text { - Kontrol }\end{array}$} & \multicolumn{5}{|c|}{ Paired Defferences } & \multirow{3}{*}{$\mathrm{t}$} & \multirow{3}{*}{$\mathrm{df}$} & \multirow{3}{*}{$\begin{array}{l}\text { Sig. (2- } \\
\text { tailled) }\end{array}$} \\
\hline & \multirow[t]{2}{*}{ Mean } & \multirow[t]{2}{*}{$\begin{array}{c}\text { Std. } \\
\text { Deviation }\end{array}$} & \multirow[t]{2}{*}{$\begin{array}{l}\text { Std. } \\
\text { Error } \\
\text { Mean }\end{array}$} & \multicolumn{2}{|c|}{$\begin{array}{c}5 \% \text { Confidence } \\
\text { Interval of } \\
\text { Difference }\end{array}$} & & & \\
\hline & & & & Lower & Upper & & & \\
\hline & 4.853 & 9.106 & 1.562 & 1.676 & 8.030 & 3.108 & 33 & .004 \\
\hline
\end{tabular}

Berdasarkan tabel uji hipotesis kelas eksperimen dan kelas kontrol, menunjukkan bahwa nilai probabilitas (signifikansi) adalah 0,004. Karena nilai signifikansi 0,004 <0,050, maka H0 ditolak. Hal ini membuktikan bahwa terdapat pengaruh penggunaan teknik akrostik terhadap keterampilan menulis puisi pada siswa kelas $\mathrm{V}$.

Berdasarkan penelitian yang telah dilakukan, ditemukan bahwa terdapat pengaruh yang signifikan pada penggunaan teknik akrostik terhadap keterampilan menulis puisi siswa kelas $\mathrm{V}$ SD Islam Al Amanah Tangerang Selatan Tahun Pelajaran 2015/2016. Hal ini dapat dilihat dari nilai rata-rata posttest kelas eksperimen sebesar 74,89 dan kelas kontrol 70,00. Perbedaan hasil keterampilan menulis puisi disebabkan karena perbedaan perlakuan guru dalam proses pembelajaran. Pada kelas eksperimen guru menggunakan teknik akrostik dalam proses pembelajaran. Sedangkan pada kelas kontrol guru hanya menggunakan metode konvensional. Hal tersebut juga telah dibuktikan oleh pengujian hipotesis yang menunjukkan bahwa nilai signifikansi $0,004<\alpha=0,050$, yang berarti H0 ditolak dan Ha diterima. Hal ini membuktikan bahwa terdapat pengaruh penggunaan teknik akrostik terhadap keterampilan menulis puisi pada siswa kelas V SD Islam Al Amanah Tangerang Selatan Tahun Pelajaran 2015/2016.

Hasil penelitian ini mendukung teori yang dinyatakan dalam buku Novi Resmini dan Dadan Juanda yang menyatakan bahwa akrostik adalah puisi yang ditulis dengan cara mengembangkan larik-larik dalam puisi melalui pengembangan huruf yang tersusun ke bawah membentuk sebuah kata. Adapun teori keterampilan menulis yang dinyatakan oleh Tarigan yaitu Keterampilan Menulis merupakan keterampilan berbahasa yang produktif dan ekspresif, karena penulis harus terampil menggunakan grafologi, struktur bahasa, dan kosakata. Dilihat berdasarkan perkembangan keterampilan menulis anak pada masa MI/SD menurut Santrock anak harus didorong untuk terus belajar menulis, karena kemampuan menulis menghendaki penguasaan berbagai unsur isi maupun kebahasaan. Maka dengan menggunakan teknik akrostik, beberapa siswa yang belum bisa menulis puisi menjadi bisa, dan siswa yang kesulitan menemukan ide untuk dijadikan sebuah puisi menjadi mudah menemukan ide. karena dengan teknik ini, siswa dapat menemukan ide atau gagasan dari sesuatu yang dikenal di sekitarnya. 
Hasil penelitian ini juga mendukung hasil penelitian Desy Pratika Reni pada tahun 2013, dengan judul "Peningkatan Keterampilan Menulis Puisi melalui Teknik Akrostik dengan Media Lagu pada Siswa Kelas V SDN Gajahmungkur 02 Semarang”, yang menyimpulkan bahwa teknik akrostik dengan media lagu dapat meningkatkan keterampilan guru, aktivitas siswa, dan keterampilan menulis puisi siswa. Sedangkan hasil penelitian Nelvin pada tahun 2015, dengan "Penerapan Teknik Akrostik melalui Aktivitas Terbimbing untuk Meningkatkan Kemampuan Menulis Puisi Siswa Kelas V SDN Doda”, yang menyimpulkan bahwa penerapan teknik akrostik meningkatkan kemampuan menulis puisi siswa kelas V SDN Doda. Adapun hasil penelitian Desak Puti Rohika, dkk pada tahun 2014, dengan judul penelitian "Pengaruh Pembelajaran Menulis Puisi dengan Teknik Akrostik terhadap Hasil Belajar Menulis Puisi dan Motivasi Berprestasi Siswa Kelas V SD di Gugus 6 Kecamatan Gianyar, yang menyimpulkan bahwa penggunaan teknik akrostik berpengaruh terhadap hasil belajar menulis puisi dan motivasi berprestasi siswa kelas V SD di Gugus 6 Kecamatan Gianyar, karena penerapan model pembelajaran teknik akrostik memberikan peluang kepada siswa untuk dapat meningkatkan kreatifitasnya, melahirkan karya seni puisi, dan dapat meningkatkan motivasinya dalam berkreatifitas dengan lebih baik. Dengan demikian penggunaan teknik akrostik dalam pembelajaran menulis puisi dapat dijadikan acuan oleh para guru dalam meningkatkan keterampilan menulis puisi siswa.

\section{SIMPULAN}

Berdasarkan hasil penelitian dan analisis data, maka dapat disimpulkan bahwa penggunaan Teknik Akrostik berpengaruh terhadap Keterampilan Menulis Puisi Siswa Kelas V SD Islam Al Amanah Tangerang Selatan Tahun Pelajaran 2015/2016. Hal ini terbukti pada peroleh rata-rata nilai posttest keterampilan menulis puisi pada siswa kelas eksperimen dengan menggunakan teknik akrostik lebih tinggi dibandingkan rata-rata keterampilan menulis puisi pada siswa kelas kontrol yang diajarkan dengan metode pembelajaran konvensional. Rata-rata nilai posttest pada kelas eksperimen sebesar 74,89 dan kelas kontrol 70,00. Perbedaan tersebut diperkuat berdasarkan Uji-t yakni uji paired sampel T Test dan diperoleh nilai probabilitas (signifikan) yaitu 0,004. Karena nilai signifikansi $0,004<\alpha=0,050$, maka $\mathrm{H}_{0}$ ditolak. Hal ini membuktikan bahwa penggunaan Teknik Akrostik Berpengaruh terhadap Keterampilan Menulis Puisi Siswa Kelas V SD Islam Al Amanah Tangerang Selatan Tahun Pelajaran 2015/2016. 


\section{DAFTAR PUSTAKA}

Arifin, Zainal. Penelitian Pendidikan. Bandung: PT. Remaja Rosdakarya, 2011.

Hanafi, Abdul Halim. Metode Penelitian Bahasa untuk Penelitian, Tesis, dan Disertasi. Jakarta: Diatik Media, 2011.

Ismawati, Esti. Metode Penelitian Pendidikan Bahasa dan Sastra. Yogyakarta: Ombak, 2012.

Nurgiyantoro, Burhan. Sastra Anak Pengantar Pemahaman Dunia Anak. Yogyakarta: Gajah Mada University Press, 2005.

Resmini, Novi dan Dadan, Juanda. Pendidikan Bahasa dan Sastra Indonesia di Kelas Tinggi. Bandung: UPI Press, 2007

Sugiyono. Metodologi Penelitian Kombinasi (Mixed Methods). Bandung: Alfabeta, 2013.

Suhadi. Peningkatan Keterampilan Menulis Puisi melalui Teknik Akrostik dengan Media Lagu. Tegal: Jurna Dinamika, 2014.

Sukmadinata, Nana Syaodih. Metode Penelitian Pendidikan. Bandung: PT Remaja Rosdakarya, 2012.

Tarigan, Henry Guntur. Menulis sebagai Suatu Keterampilan Berbahasa. Bandung: Angkasa, 2008. 